\begin{tabular}{lll}
\hline Volume 6 & Nomor 1 & April 2018 \\
\hline
\end{tabular}

\title{
Pengaruh Gaya Kepemimpinan Transaksional Terhadap Kinerja Dan Kepuasan Perawat pada Layanan Rawat Inap Rumah Sakit Umum Puri Asih Salatiga
}

\author{
Hidayat Waluyo*Sutopo Patria Jati** \\ *RSU. Puri Asih Salatiga. \\ **Fakultas Kesehatan Masyarakat, Universitas Diponegoro, Semarang. \\ Email: hidayatwaluyo.hw@gmail.com
}

\section{ABSTRACT:}

Factors that can affect both the poor performance of employees one of which is the style of leadership. This study was conducted to determine whether transactional leadership style has influence on performance and job satisfaction as intervining, the influence of job satisfaction on nurse performance RSU. Puri Asih Salatiga. Populasi used is inpatient nurses as many as 60 people. Data analysis with SEM (structure equation modeling) testing is done with smart software PLS. The results obtained in this study: (1) Transactional leadership style has positive and significant impact on job satisfaction, (2) Transactional leadership style has a positive and significant effect on employee performance, (3) Satisfaction does not affect to employee's performance, (4) Transactional leadership style does not affect to employee performance through satisfaction as intervining. Suggestion to use the remuneration system in order to achieve better satisfaction.
Keywords: Transactional Leadership, Employee Performance, Employee Satisfaction

\section{PENDAHULUAN}

Dalam menghadapi era pasar bebas penuh tantangan yang ketat, bebagai macam aspek keunggulan dibutuhkan oleh setiap organisasi dalam rangka mencapai tujuannya. Faktor utama yang dibutuhkan dalam rangka mewujudkan harapan organisasi tersebut adalah faktor sumber daya manusia. Manusia yang bekerja dalam sebuah perusahaan, menyumbangkan tenaga baik fisik maupun pikiran dan mendapatkan imbalan atau jasa sesuai dengan peraturan atau perjanjian disebut sebagai karyawan. Setiap organisasi atau perusahaan diharapkan mampu mengelola dan mengatur aspek sumber daya manusia yang dimilikinya dengan sebaik mungkin. Terkelolanya sumberdaya manusia melalui manajemen sumber daya manusia yang baik, tujuan dan harapan perusahaan akan tercapai.

Peranan atasan atau sering disebut pimpinan sangatlah besar bagi keberhasilan perusahaan dalam mencapai tujuan. Faktor yang dapat mempengaruhi baik buruknya kinerja seorang karyawan salah satunya adalah gaya kepemimpinan. 
Keberhasilan dan kegagalan suatu perusahaan ditentukan oleh kepemimpinan, bentuk kepemimpinan yang efektif akan berdampak pada kemajuan perusahaan ${ }^{\mathbf{1}}$. Kepemimpinan adalah kemampuan untuk mempengaruhi suatu kelompok ke arah tercapainya tujuan ${ }^{2}$. Gaya kepemimpinan transaksional adalah kemampuan seorang pemimpin yang selalu memberikan imbalan ( reward ) sesuai dengan kesepakatan, menetukan apa yang harus dilakukan bawahan untuk mencapai sasaran sendiri dan sasaran organisasi, mengklasifikasikan persyaratan tersebut dan membantu bawahan menjadi yakin bahwa mereka dapat mencapai sasarannya dengan mengerahkan upaya yang diperlukan ${ }^{3}$.

Peneliti memilih kepemimpinan transaksional sebagai variabel yang akan diteliti, karena berdasarkan hasil survey dan observasi yang telah dilakukan di RSU. Puri Asih Salatiga lebih condong ke arah kepemimpinan transaksional. Kebijakan pimpinan mengikuti konsep gaya kepemimpinan transaksional yang meliputi adanya Contingen Reward, Active Management by Exception dan Passive Management by Exception. Apabila karyawan dapat mencapai target sesuai BOR maka karyawan akan mendapatkan kompensasi tambahan. Pencapaian BOR kunjungan pasien $60 \%$ maka perawat akan mendapatkan tambahan pendapatan sebesar $60 \%$ dari asuhan keperawatan (Askep) yang mereka kerjakan sesuai prosedur, jika $80 \%$ pencapaian BOR-nya yang mereka

dapatkan 80\% dari Askep yang mereka kerjakan, demikian seterusnya.

Perawat dalam menjalankan tugas keperawatannya didasari dengan SOP
(Standar Operasional Pelaksanaan) apabila dalam pelaksanaan terjadi kesalahan, maka akan dikenai peringatan, sampai sanksi, dipindahkan atau diturunkan jabatannya. Apabila surat peringatan sampai tiga kali, maka diberhentikan/ mengundur kan diri. Pada karyawan baru diberlakukan penggajian $80 \%$ dari gaji pokok selama satu tahun, pendapatan yang diterima karyawan baru masih relatif kecil karena diberlakukan sistem point bedasarkan lamanya bekerja, sehingga pada tahun pertama masih sangat kecil, ini yang sering dikeluhkan pada karyawan baru. Dari perihal ini maka peneliti menggunakan kepemimpinan transaksional sebagai variabel penelitian.

Salah satu komponen kepuasan kerja karyawan ialah kepemimpinan, karena apabila karyawan merasa puas dengan perlakuan perusahaan seperti: pekerjaan, lingkungan kerja, kepemimpinan, serta hasil yang diberikan maka akan meningkatkan produktivitas, kedisiplinan, serta kepuasan kerja dikarenakan cara memimpin dalam mengkoordinasikan karyawan ${ }^{4}$.

Hasil observasi peneliti didapatkan data turn over yang tinggi untuk perawat. RSU Puri Asih merupakan sebuah rumah sakit umum swasta milik perseorangan, yang berlokasi di Salatiga, Jawa Tengah. Jumlah perawat berkisar 60 orang, saat ini menghadapi permasalahan turn over yang cukup tinggi dalam tiga tahun belakangan ini, th 2014 angka turn over mencapai 20,6\%, th 2015 angka turn over mencapai 7,4\% dan th 2016 angka turn over mencapai $11,7 \%$. Dengan data turn over yang tinggi mendukung pemahaman bahwa rumah sakit Puri Asih adalah rumah sakit swasta yang akan dijadikan batu 
loncatan untuk karyawan terutama yang belum mempunyai pengalaman kerja, ini ditunjukkan dengan banyaknya turn over dominan pada karyawan yang masih kurang dari satu tahun.

Hasil penelitian sebelumnya menyatakan adanya hubungan yang negatif signifikan antara kepuasan kerja dengan intensi turn over perawat di RSU Puri Asih Salatiga ${ }^{5}$. Intensi turn over adalah keinginan seseorang untuk keluar dari perusahaan. Tingkat intensi turn over adalah kriteria yang cukup baik untuk mengukur stabilitas yang terjadi di organisasi tersebut, dan juga bisa mencerminkan kinerja dari organisasi ${ }^{6}$. Hal ini mengapa kepuasan kerja dipilih sebagai variabel intervining/ variabel penyela yang secara teoritis mempengaruhi hubungan kepemimpinan transaksional dengan kinerja karyawan menjadi hubungan yang tidak langsung dan tidak dapat diamati dan diukur.

Adanya peraturan RSU. Puri Asih tentang keterlambatan kedatangan, bila karyawan terlambat datang 15 menit dari jadwal sift jaga. Hal ini tidak ada tindak lanjutnya. Lemahnya monitoring dan evaluasi system absensi karyawan merupakan permasalahan yang perlu dicermati kaitannya dengan kepuasan perawat rawat inap RSU. Puri Asih Salatiga.

Tujuan umum dari penelitian ini adalah untuk mengetahui informasi secara empiris mengenai adanya gaya kepemipinan transaksional berpengaruh terhadap kepuasan kerja dan kinerja perawat RSU. Puri Asih Salatiga. Tujuan khusus adalah menganalisa pengaruh gaya kepemimpinan transaksional berpengaruh terhadap kepuasan kerja perawat rawat inap RSU Puri Asih Salatiga sebeagai variabel intervining, menganalisa pengaruh kepuasan terhadap kinerja perawat rawat inap RSU Puri Asih Salatiga.

Rumah Sakit merupakan organisasi yang sangat unik dan kompleks. Dikatakan unik karena rumah sakit menghasilkan jasa pelayanan perhotelan dan jasa pelayanan kesehatan kepada pasien rawat inap dan rawat jalan. Dikatakan komplek karena rumah sakit merupakan suatu organisasi padat karya dengan latar belakang pendidikan karyawan yang berbeda. Tidaklah mudah memadupadankan keunikan dan kekomplekan tersebut. Beberapa hasil penelitian terdahulu menemukan bahwa gaya kepemimpinn transaksional berpengaruh positif dan signifikan terhadap kepuasan kerja.

Gaya kepemimpianan transaksional berpengaruh positif dan signifikan terhadap kinerja karyawan. Kepuasan kerja berpengaruh positif dan signifikan terhadap kinerja karyawan. Kepuasan kerja menjadi variabel intervining dalam pengaruh gaya kepemimpinan transaksional terhadap kinerja karyawan ${ }^{7}$. Gaya kepemimpinan tranformasional dan gaya kepemimpinan transaksional berpengaruh positif dan signifikan terhadap kinerja organisasi, tetapi gaya kepemimpinan transaksional secara parsial tidak berpengaruh terhadap kinerja organisasi ${ }^{8}$. Gaya kepemimpinan transaksional lebih berperan dari pada kepemimpinan Transformasional ${ }^{9}$. Gaya kepemimpinan berpengaruh signifikan terhadap kinerja perawat, variabel kepuasan kerja tidak berpengaruh terhadap kinerja perawat, gaya kepemimpinan dan kepuasan kerja secara simultan berpengaruh terhadap kinerja perawat yang 
bertugas di ruang rawat inap ${ }^{\mathbf{1 0}}$. Kepemimpinan transaksional berpengaruh terhadap kepuasan kerja pada karyawan. Kepemimpian transaksional berpengaruh terhadap kinerja karyawan ${ }^{\mathbf{1 1}}$.

\section{METODE PENELITIAN}

Pendekatan yang digunakan dalam penelitian ini adalah pendekatan Kuantitatif (positivism) yang berbentuk asosiatif karena penelitian ini bertujuan untuk mengetahui pengaruh antara dua variabel atau lebih. Penelitian ini menggunakan hipotesis dan rancangan penelitian berbentuk penelitian survei, yaitu riset yang menampilkan hubungan sebab akibat antara variabel bebas (independent variable) yaitu Gaya Kepemimpinan Transaksional; variabel antara (intervening variable) yaitu Kepuasan kerja karyawan dan variabel terikat (dependent variable) yaitu Kinerja karyawan.

\section{HASIL DAN PEMBAHASAN}

\section{A. Analisa Data dan Pembahasan}

\section{Analisis Deskriptif}

Pada penelitian ini telah dilakukan kuisioner terhadap 60 responden. Karakteristik responden digambarkan sebagai berikut:

Tabel 1. Distribusi Frekuensi Karakter

\begin{tabular}{lcc}
\multicolumn{3}{c}{ Responden } \\
\hline $\begin{array}{c}\text { Karakteristik } \\
\text { Responden }\end{array}$ & $\mathrm{f}$ & $\%$ \\
& & \\
\hline Jenis Kelamin & & \\
Laki-Laki & 9 & 15,0 \\
Perempuan & 51 & 85,0 \\
\hline Pendidikan & & \\
\hline
\end{tabular}

\begin{tabular}{lcc}
\hline \multicolumn{1}{c}{ Karakteristik } & $\mathrm{f}$ & $\%$ \\
Responden & & \\
\hline DIII Keperawatan & 47 & 78,3 \\
S1 Keperawatan & 7 & 11,7 \\
Profesi Ners & 6 & 10,0 \\
\hline
\end{tabular}

a. Karakteristik responden berdasarkan jenis kelamin

Hasil kuisioner pada penelitian ini menunjukkan bahwa sebagian besar responden berjenis kelamin perempuan $(85,0 \%)$, dan hanya sebagian kecil $(12,0 \%)$ adalah laki-laki. Secara rinci dapat dilihat pada tabel 1 .

b. Karakteristik reponden berdasarkan kualifikasi pendidikan

Hasil kuisioner pada penelitian ini menunjukkan bahwa sebagian besar responden mempunyai kualifikasi pendidikan DIII Keperawatan (78,3\%), sisanya mempunyai kualifikasi pendidikan S1 Keperawatan dan S1 Profesi Ners masing-masing $11,7 \%$ dan $10,0 \%$. Secara rinci dapat dilihat pada tabel 1 .

C. Karakteristik responden berdasarkan umur dan masa kerja

Hasil kuisioner pada penelitian ini menunjukkan bahwa rerata umur responden 27,6 tahun dengan umur minimal 22 dan masimal 41 tahun. Sedang rerata masa kerja responden adalah 50,6 bulan dengan masa kerja nimimal 2 dan makasimal 180 bulan (15 tahun). Secara rinci dapat dilihat pada tabel 2 .

Tabel 2. Karakteristik responden berdasarkan masa kerja 


\begin{tabular}{clll}
\hline No. & Karakteristik & $\begin{array}{l}\text { Rerata } \\
\pm \mathrm{SD}\end{array}$ & $\begin{array}{l}\text { Min - } \\
\text { Mak }\end{array}$ \\
\hline 1 & Umur & $27,6 \pm$ & $22-41$ \\
& (tahun) & 5,2 & \\
2 & Masa Kerja & $50,6 \pm$ & 2. - 180 \\
& (bulan) & 46,6 & \\
\hline
\end{tabular}

\section{Analisis Univariat}

\section{a. Variabel Kepemimpinan}

Kuisioner dengan 60 responden telah dilakukan untuk mengetahui gambaran tentang kepemimpinan di Rumah Sakit Puri Asih Salatiga. Pada variabel kepemimpinan ini digunakan 12 pertanyaan (sebagai indikator kepemimpinan) dengan kode X1 sampai dengan X12. Informasi yang diperoleh dilakukan pengolahan seperti pada tabel 5 .

Tabel 3. Distribusi frekuensi jawaban responden tentang aspek kepemimpinan di RS. Puri Asih Salatiga tahun 2017.

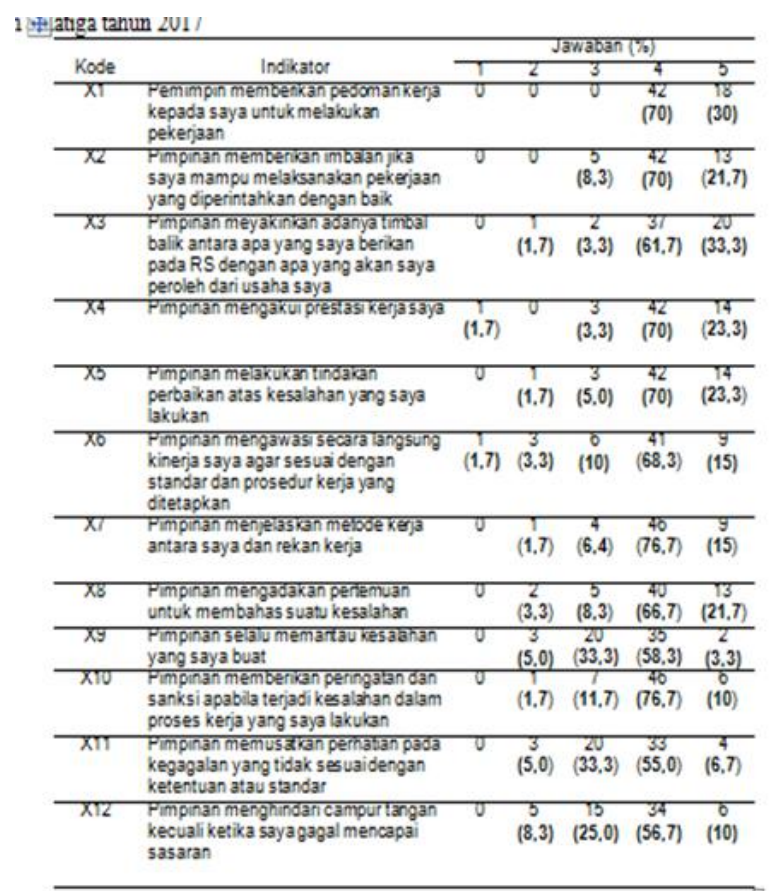

Berdasarkan tabel 6 dapat diketahui bahwa : i. Contingen Reward (x1,x2,x3,x4) responden yang paling banyak menyatakan setuju sebanyak 42 responden $(70 \%)$ pada pimpinan mengakui prestasi kerja saya, dan yang paling banyak menyatakan sangat setuju 20 responden $(33,3 \%)$ pada Pimpinan meyakinkan adanya timbal balik antara apa yang saya berikan pada RS dengan apa yang yang akan saya peroleh dari usaha saya, dan responden yang menyatakan kurang setuju sebanyak 5 responden $(8,3 \%)$ pada Pimpinan memberikan imbalan jika saya mampu melaksanakan pekerjaan yang diperintahkan dengan baik, dan responden yang menyatakan sangat tidak setuju 1 responden $(1,7 \%)$ pada Pimpinan mengakui prestasi kerja saya. Hal ini sesuai dengan dimensi Contingent Reward yang ditunjukkan dalam bentuk perilaku pemimpin yang memeberitahukan kepada anggota mengenai kegiatan yang harus dilakukan jika ingin memperoleh imbalan tertentu.

\section{ii. Active Mangement by Exception} $(x 5, x 6, x 7, x 8)$ responden yang paling banyak menyatkan setuju sebanyak 46 responden $(76,7 \%)$ pada Pimpinan menjelaskan metode kerja antara saya dengan rekan kerja, dan responden yang menyatakan sangat setuju sebanyak 14 responden $(23,3 \%)$ pada Pimpinan melakukan tindakan perbaikan atas kesalahan yang saya lakukan, dan responden yang menyatakan kurang setuju sebanyak 6 responden (10\%) pada Pemimpin mengawasi secara langsung kinerja saya agar sesuai dengan standar dan prosedur kerja yang ditetapkan, dan responden yang menyatakan tidak 
setuju sebanyak 3 responden $(3,3 \%)$ pada Pemimpin mengawasi secara langsung kinerja saya agar sesuai dengan standar dan prosedur kerja yang ditetapkan, dan responden yang menyatakan sangat tidak setuju sebanyak 1 responden (1,7\%) pada Pemimpin mengawasi secara langsungkinerja saya agar sesuai dengan standar dan prosedur kerja yang ditetapkan. Kepemimpinan ini merupakan perilaku yang memantau pelaksanaan tugas dan masalah yang mungkin muncul serta melakukan tindakan perbaikan untk memelihara kinerja yang telah ada.

\section{iii.Passive Management by Exception} (x9,x10,x11,x12) Responden yang paling banyak menyatakan setuju sebanyak 46 responden $(76,6 \%)$ yaitu Pimpinan memberikan peringatan dan sanksi apabila terjadi kesalahan dalam proses kerja yang saya lakukan, jumlah responden yang menyatakan kurang setuju sebanyak 20 responden $(33,3 \%)$ pada pimpinan selalu memantau kesalahan yang saya buat,kenudian responden yang menyatakan sangat setuju sebanyak 6 responden $(10 \%)$ pada Pimpinan menghindari campur tangan kecuali ketika saya gagal mencapai sasaran, responden yang tidak setuju sebanyak 5 responden $(8,3 \%)$ pada Pimpinan menghindari campur tangan kecuali ketika saya gagal mencapai sasaran, dan responden yang menyatan sangat tidak setuju tidak ada. Kepemimpinan transaksional akan memebrikan peringatan dan sanksi kkepada bawahannya apabila terjadi kesalahan dalam proses yang dilakukan bawahan, namun apabila proses yang dilaksanakan masih berjalan sesuai standard dan prosedur, maka pemimpin transaksional tidak memberikan evaluasi apapun kepada bawahan.

b. Variabel Kepuasan

Kuesioner dengan 60 responden telah dilakukan untuk mengetahui gambaran tentang kepuasan karyawan di Rumah Sakit Puri Asih Salatiga. Pada variabel kepuasan ini digunakan 10 pertanyaan (sebagai indikator kepuasan) dengan kode M1 sampai dengan M10. Informasi yang diperoleh dilakukan pengolahan seperti pada tabel 3 .

Tabel 3. Distribusi frekuensi jawaban responden tentang aspek kepusan di RS. Puri Asih Salatiga tahun 2017.

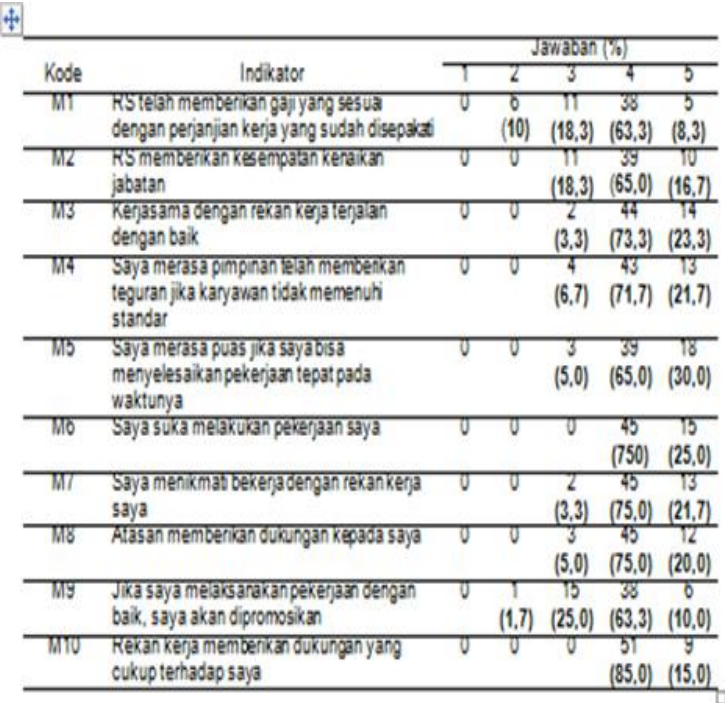

Berdasarkan tabel 4.9 dapat diketahui bahwa:

Berdasarkan tabel 3 dapat diketahui bahwa :

i. Indikator Gaji / upah/ pay (M1), responden yang menyatakan paling banyak adalah setuju sebesar 38 responden $(63,3 \%)$ pada $\mathrm{RS}$ telah memberikan gaji yang sesuai dengan perjanjian kerja yang sudah disepakati, kurang setuju sebanyak 11 responden $(18,3 \%)$, sangat setuju sebanyak 5 responden $(8,3 \%)$ kurang setuju sebanyak 6 responden $(10 \%)$, hal ini 
menggagambarkan indikator gaji pada variabel kepuasan di Rs. Puri Asih berkisar 71,3\%.

ii.Indikator promosi (M2), (M9), responden yang paling banyak menyatakan setuju sebanyak 39 responden (65\%) kurang setuju 15 responden $(25 \%)$, responden yang menyatakan sangat setuju sebanyak 5 responden $(8,3 \%)$ dan responden yang menyatakan sangat tidak setuju 1 responden $(1,7 \%)$ hal ini menunjukkan untuk indikator promosi variabel kepuasan di RSU Puri Asih Salatiga berkisar $90 \%$.

iii. Indikator pekerjaan itu sendiri (M5), (M6), resonden yang paling banyak menyatakan setuju sebanyak 42 responden (70\%), sangat setuju yang menyatakan 16 responden (26,7\%), kurang setuju sebanyak 2 responden $(3,3 \%)$. Variabel kepuasan dengan indicator pekerjaan itu sendiri RSU Puri Asih Salatiga berkisar 96,7\%.

iv. Indikator penyelia (supervision) (M 4), (M8) responden yang menyatakan setuju sebanyak 43 (71,7\%), responden yang menyatakan sangat setuju sebanyak 13 (12,7\%), dan yang menyatakan kurang setuju sebanyak 4 $(6,7 \%)$ Untuk variabel kepuasan dengan indikator penyelia di RSU Puri Asih Salatiga berkisar $84.4 \%$.

v. Indikator teman sekerja (M3), (M7), (M10) Responden yang menyatakan setuju sebesar 46 responden $(76,7 \%)$, responden yang menyatakan sangat setuju sebanyak 12 responden (20\%), responden yang kurang setuju sebanyak 2 responden (3,3\%). Variabel kepusan dengan indicator teman sekerja berkisar $86,7 \%$ menunjukkan di RSU.Puri Asih Salatiga teman sekerja memberikan prosentase berkisar $86,7 \%$

\section{Variabel Kinerja}

Kuisioner dengan 60 responden telah dilakukan untuk mengetahui gambaran tentang kinerja kaeyawan di Rumah Sakit Puri Asih Salatiga. Pada variabel kinerja ini digunakan 10 pertanyaan (sebagai indikator kinerja) dengan kode Y1 sampai dengan Y10. Informasi yang diperoleh dilakukan pengolahan seperti pada tabel 8 .

Tabel 4. Distribusi frekuensi jawaban responden tentang aspek kinerja karyawan di RS. Puri Asih Salatiga tahun 2017

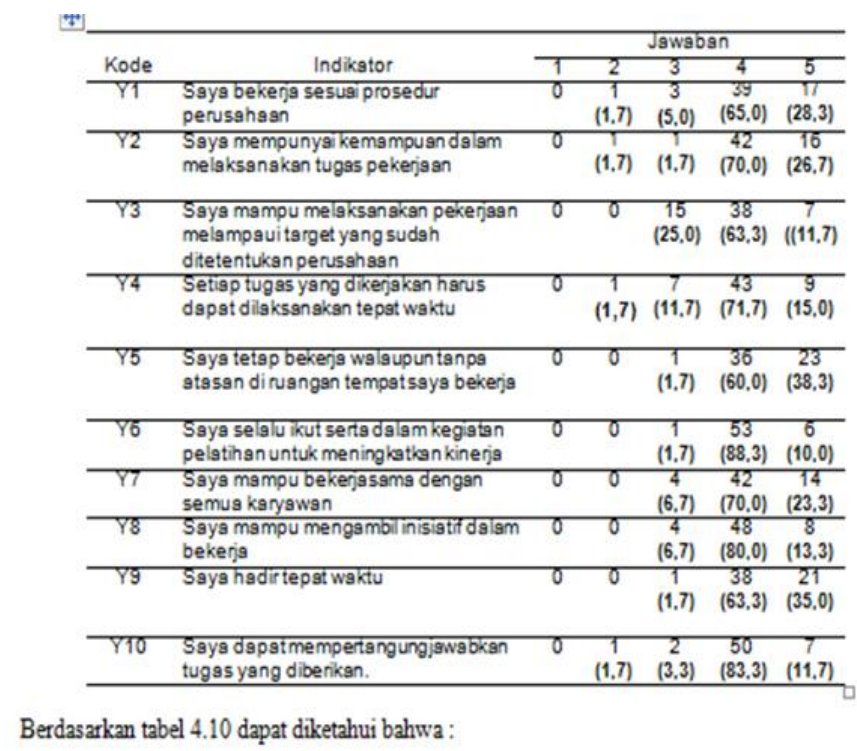

Berdasarkan tabel 4 dapat diketahui bahwa :

i. Indikator kualitas pada variabel kinerja (Y1), (Y6) responden yang paling banyak menyatakan setuju sebanyak 46 responden $(76,7 \%)$, responden yang menyatakan sangat setuju sebesar 13 responden $(21,7 \%)$, yang menyatakan kurang setuju sebanyak 1 ( $1,6 \%)$. Variabel kinerja melalui indikator kualitas di RSU.Puri Asih Salatiga berkisar $98,4 \%$.

ii.Indikator kuantitas pada variabel kinerja (Y3 ), (Y7) responden yang 
menyatakan setuju sebanyak 40 responden $(66,7 \%)$ sedang responden yang menyatakan sangat setuju sebanyak 11 responden (18,3\%) responden yang menyatakan kurang setuju sebanyak 9 responden (15\%). Variabel kinerja melalui indicator kuantitas di RSU. Puri Asih Salatiga brkisar $85 \%$.

iii. Indikator ketepatan waktu pada variabel kinerja ( Y4 ), (Y9) responden yang menyatakan setuju sebanyak 44 responden $(73,3 \%)$ responden ang mentakan sangat setuju sebanyak 15 responden (25\%), responden yang menyatakan kurang setuju sebanyak 1 responden $(1,7 \%)$.

iv. Indikator komitmen kerja pada variabel kinerja (Y2), (Y8) rsponden yang menyatakan setuju sebanyak 45 responden $(75 \%) \mathrm{n}$ responden yang menyatakan sangat setuju sebanyak 12 responden (20\%), responden yang menyatakan kurang setuju sebanyak 2 responden (3,3\%), untuk responden yang menyatakan sangat tidak setuju 1 responden $(1,7 \%)$.

v. Indikator tanggung jawab pada variabel kinerja (Y5), (Y10) responden yang menyatakan setuju sebanyak 42 responden $(70 \%)$, responden yang menyatakan sangat setuju sebanyak 15 responden $(25 \%)$, responden yang menyatakan kurang setuju 2 responden $(3,3 \%)$, responden yang tidak setuju sebanyak 1 responden $(1,7 \%)$.

\section{Analisis Bivariate}

a. Validitas dan reliabilitas indikator variabel Kepemimpinan,Kepuasan Kerja, dan Kinerja.

Uji validitas dan reliabilitas indikator variabel laten dilakukan dengan menggunakan softwre Smart PLS. Validitas sebuah indikator ditunjukkan dengan besaran nilai "Loading" atau "original sample estimate" dari masingmasing indikator terhadap variabel latennya. Dalam penelitian ini, indikator dikatakan valid bila nilai Loadingnya $>0,5$ atau nilai statistik $\mathrm{T}>1,96$. Sedang untuk melihat apakah indikator-indikator dari suatu variabel laten dikatakan reliabel digunakan nilai "Composite Reliability". Suatu indikator dikatakan reliabel bila nilai "Composite Reliability > 0,7. Hasil analaisis validitas dan reliabilitas dengan Smart PLS diperoleh hasil seperti pada tabel 5 .

Tabel 5. Hasil analisis validitas indikator variabel laten (Outer Mode)

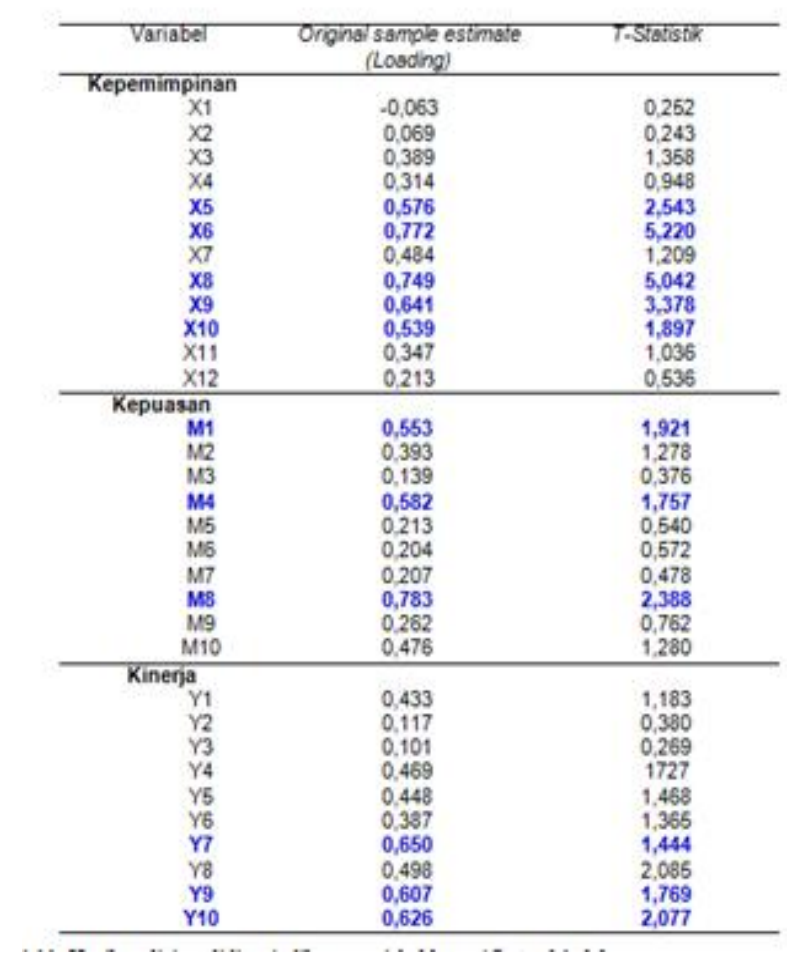

Dari tabel 5 dapat diketahui indikatorindikator mana yang valid dengan batasan nilai "Loading" $>0,5$ atau nilai statistik $\mathrm{T}>1,96$. Hasil analisis ini mendapatkan ada lima indikator dari variabel laten 
kepemimpinan yang dinilai valid yaitu $\mathrm{X}$, $\mathrm{X6}$, X8, X9, dan X10. Sedang untuk variabel laten kepuasan terdapat tiga indikator yang dinilai valid yaitu M1, M4, dan M8. Untuk variabel kinerja terdapat tiga indikator yang dinilai valid yaitu Y7, Y9, dan Y10. Indikator-indikator yang valid dari ketiga variabel laten tersebut akan dugunakan untuk analisis SEM tahap kedua dengan tidak mengikutkan indikator dengan nilai "Loading” kurang dari 0,5.

Disamping harus memenuhi syarat validitas, indikator suatu variabel laten juga harus mempunyai syarat reliabilitas. Untuk ukuran reliabitas, hasil analisis dengan Smart PLS akan memberikan nilai "Composite Reliability" dengan batasan indikator dikatakan reliabel bila nilai "Composite Reliability" lebih dari 0,7. Hasil analisis reliabilitas dapat dilihat pada tabel 6 .

Tabel 6. Nilai Reliabilitas indikator variabel laten

\begin{tabular}{cc}
\hline Variabel laten & Composite Reliability \\
\hline Kepemimpinan & 0.734 \\
Kepuasan & 0.641 \\
Kinerja & 0,707 \\
\hline
\end{tabular}

Dari tabel 6 dapat diketahui bahwa nilai "Composite Reliability" variabel kepemimpinan dan kinerja lebih dari 0,7. Sedang untuk variabel kepuasan hampir mendekati 0,7 (kurang reliabel).

Secara diagram skematis hasil analisis validitas dan reliabilitas dari variabel kepemimpinan, kepuasan, dan kinerja dapat dilihap pada Gambar 1.

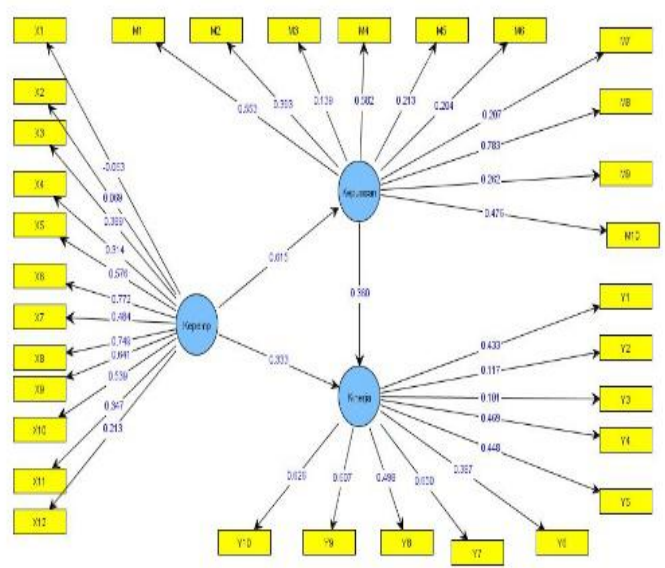

Gambar 1. Hasil analisis validitas variabel kepemimpinan, kepuasan, dan kinerja

Evaluasi tahap pertama ini juga dilakukan untuk melihat pengaruh secara simultan variabel laten kepemimpinan, Kepuasan, dan kinerja dengan menggunakan semua indikator dari masing-masing variabel laten. Hasil analisis ditunjukan dengan nilai original parameter estimate Inner Model seperti tabel 7.

Tabel 7. Hasil analisis pengaruh kepemimpinan, kepuasan, dan kinerja (Inner Model)

\begin{tabular}{lcc}
\hline \multicolumn{1}{c}{ Variabel } & $\begin{array}{c}\text { Original semple estimatie } \\
\text { (Koefisien regresi) }\end{array}$ & T.Siatistic \\
\hline Kepemimpinan $\rightarrow$ Kepplasan & 0,615 & 5,666 \\
Kepemimpinan $\rightarrow$ Kinerija & 0,333 & 0,939 \\
Kepuasan $\rightarrow$ Kineria & 0,360 & 0,913 \\
\hline
\end{tabular}

Berdasarkan hasil analisis pada tabel 4.13 dapat diketahui bahwa variabel kepemimpin berpengaruh positip dan signifikan terhadap kepuasan karyawan dengan koefisien regresi sebesar 0,615 dan statistik $\mathrm{T}$ sebesar 5,666 (>1,96). Akan tetapi Variabel kepemimpinan tidak berpengaruh terhadap kinerja karyawan (nilai statistik $\mathrm{T}<1,96$ ). Begitu juga, variabel kepuasan karyawan tidak 
berpengaruh terhadap kinerja karyawan dengan nilai statistik $\mathrm{T}$ kurang dari 1,96. Hal ini terjadi karena beberapa indikator dari masing-masing variabel laten menunjukkan nilai validitas (Loading) yang rendah (kurang dari 0,5).

\section{Analisis Structural Equation Modeling (SEM) dengan Smart PLS}

Analisis tahap pertama telah dilakukan dengan mengevaluasi outer model (validitas), reliabilitas ("Composite Reliability), dan inner model (koefisien regresi) seperti telah dilakukan sebelumnya. Selanjutnya dilakukan analisis tahap kedua, dengan tidak mengikutkan indikator-indikator yang tidak valid (nilai loading kurang dari 0,5). Hasil analisis diuraikan sebagai berikut.

a. Validitas dan reliabilitas (outer model)

Evaluasi terhadap validitas indikator variabel laten setelah dilakukan reduksi beberapa indikator yang tidak valid diperoleh hasil bahwa lima indikator variavel kepemimpinan dinyatakan valid karena nilai statisti $\mathrm{K}$ lebh besar dari 1,96. Begitu juga pada variabel kepuasan, indikator dinyatakan valid (nilai statistik $\mathrm{T}>$ 1,96). Akan tetapi, pada variabel kinerja hanya dua indikator yang dinyatakan valid (Y7 dan Y10), sedang Y9 nilai statistik $\mathrm{T}$ nya lebih kecil dari 1,96 (valid). Mengingat jumlah indikator yang tersisa tinggal sedikit (tiga indikator), maka tidak lagi dilakukan reduksi indikator dan analisis tahap berikutnya. Sehingga hasil analisis ini merupakan hasil final dalam penelitian ini.

Tabel 8. Hasil evaluasi outer model (validitas) variabel kepemimpinan, kepuasan, dan kinerja tahap 2 (akhir).

\begin{tabular}{rcc}
\hline Variabel & Original sample estimate (Loading) & T-Statistic \\
\hline Kepemimpinan & & \\
X5 & 0,610 & 2,011 \\
X6 & 0,782 & 8,437 \\
X8 & 0,777 & 6,587 \\
X9 & 0,692 & 7,545 \\
X10 & 0,504 & 2,208 \\
\hline Kepuasan & & \\
M1 & 0,623 & 4,362 \\
M4 & 0,676 & 2,814 \\
M8 & 0,827 & 3,036 \\
\hline Kinerja & & \\
Y7 & 0,760 & 5,634 \\
Y9 & 0,480 & 1,345 \\
Y10 & 0,823 & 3,745 \\
\hline
\end{tabular}

Selain evaluasi validitas, pada ahap dua ini juga dilakukan asesmen terhadap reliabilitas indikator variabel penelitian secara komposit. Hasil analisis menunjukkan bahwa semua indikator variabel kepemimpinan, kepuasan, dan kinerja dinyatakan reliabel dengan ditunjukkan oleh nilai "Composite Reliability" lebih besar dari 0,7. Nilai reliabilitas secara rinci dapat dilihat pada tabel 9 .

Tabel 9. Reliabilitas indikator variabel kepempimpinan, kepuasan, dan kinerja

\begin{tabular}{ll}
\hline Variabel & Composite Reliability \\
\hline Kepemimpinan & 0.809 \\
Kepuasan & 0.755 \\
Kinerja & 0.738
\end{tabular}

b. Pengaruh kepemimpinan,kepuasan, dan kinerja (inner Model)

Setelah dilakukan reduksi indikator yang tidak valid dari masing-masing variabel laten, selanjutnya dilakukan analisis secara simultan pengaruh variabel kepemimpinan, kepuasan, dan kinerja dengan Smart PLS. Asesmen dilakukan dengan mengevaluasi inner model untuk 
melihat pengruh variabel kepemimpinan terhadap kepuasan, kepemimpinan terhadap kinerja, serta kepuasan terhadap kinerja. Hasil analisis seperti terlihat pada tabel 10.

Tabel 10. Hasil analisis pengaruh kepemimpinan dan kepuasan terhadap kinerja

\begin{tabular}{lll}
\hline Variabel & $\begin{array}{l}\text { Original sample estimate } \\
\text { (koefisien regresi) }\end{array}$ & T-Statistic \\
\hline Kepemimpinan $\rightarrow$ Kepuasan & 0,586 & 6,080 \\
Kepemimpinan $\rightarrow$ Kinerja & 0,473 & 2,440 \\
Kepuasan $\rightarrow$ Kinerja & 0,160 & 0,776 \\
\hline
\end{tabular}

Hasil analisis pada tabel 10 menunjukkan bahwa ada pengaruh positip dan signifikan variabel kepemimpinan terhadap kepuasan karyaran dengan nlai koefisien regresi 0,586 dengan nilai statistik $\mathrm{T}$ sebesar 6,080 (lebih besar dari 1,96). Variabel kepemimpinan juga berpengaruh positip dan signifikan dengan koefisien regresi sebesar 0,473 dengan nilai statistik $\mathrm{T}$ sebesar 2,240 (lebih besar dari 1,96). Namun Variabel kepuasan tidak berpengaruh terhadap kinerja karyawan dengan nilai koefisiesn regresi sebesar 0,160 dan nilai statistik $\mathrm{T}$ sebesar 0,776 (lebih kecil dari 1,96). Secara skematis, hasil analisis tersebut seperti pada gambar 2.

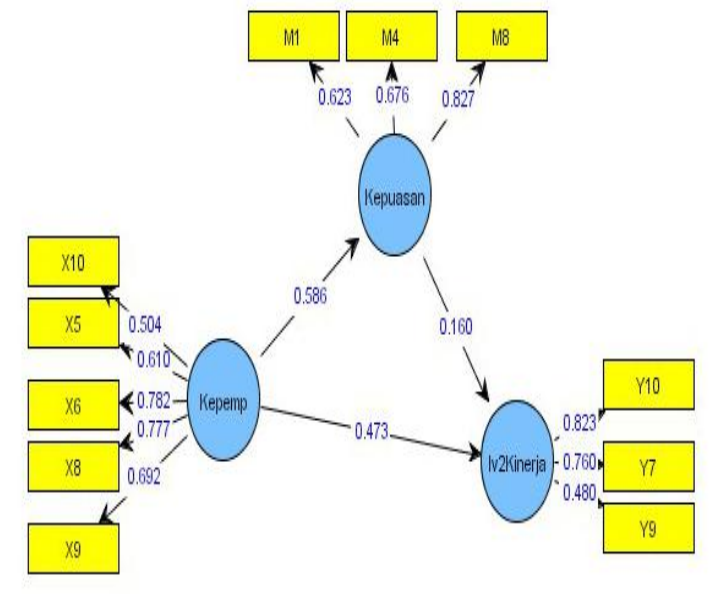

Gambar 2. Hasil analisis pengaruh

C. Pengaruh Kepemimpinan terhadap Kinerja melalui variabel intervening kepuasan dihitung sebagai berikut :

Tabel 11 Hasil analisis pengaruh langsung dan tidak langsung Kepemimpinan terhadap kinerja

\begin{tabular}{lcc}
\hline Jalur & $\begin{array}{c}\text { Perhit } \\
\text { ungan }\end{array}$ & $\begin{array}{c}\text { Nilai } \\
\text { koefisioen } \\
\text { pengaruh }\end{array}$ \\
\hline $\begin{array}{l}\text { Kepemp } \\
\text { × Kepuasan }\end{array}$ & $\begin{array}{c}0,586 \\
\mathrm{x}\end{array}$ & 0,094 \\
tidak langsung) & 0,160 & \\
$\begin{array}{l}\text { Kepemp } \\
\text { (pengaruh Kinerja }\end{array}$ & 0,473 & 0,473 \\
\hline Pengaruh total & & \\
\hline
\end{tabular}

Melihat analisa tabel 11, maka dapat dinyatakan bahwa pengaruh tidak langsung, Kepemimpinanan terhadap Kinerja malalui variabel intervening Kepuasan diperoleh nilai koefisien sebesar 0,094. Nilai inI sangat kecil sehingga dapat disimpulkan bahwa variabel intervening Kepuasan justru melemahkan pengaruh Kepemimpinan terhadap kinerja. Adapun 
pengaruh total dari variabel Kepemimpinana terhadap Kinerja diperoleh sebesar 0.567 .

\section{Modifikasi model}

Setelah dilakukan modifikasi model dengan bangun konsep kepuasan berpengaruh terhadap kepemimpinan, kepemimpinan berpengaruh terhadap kinerja (dimana kepemimpinan sebagai variabel intervening), maka diperoleh hasil estimete parameter seperti gambar 3 .

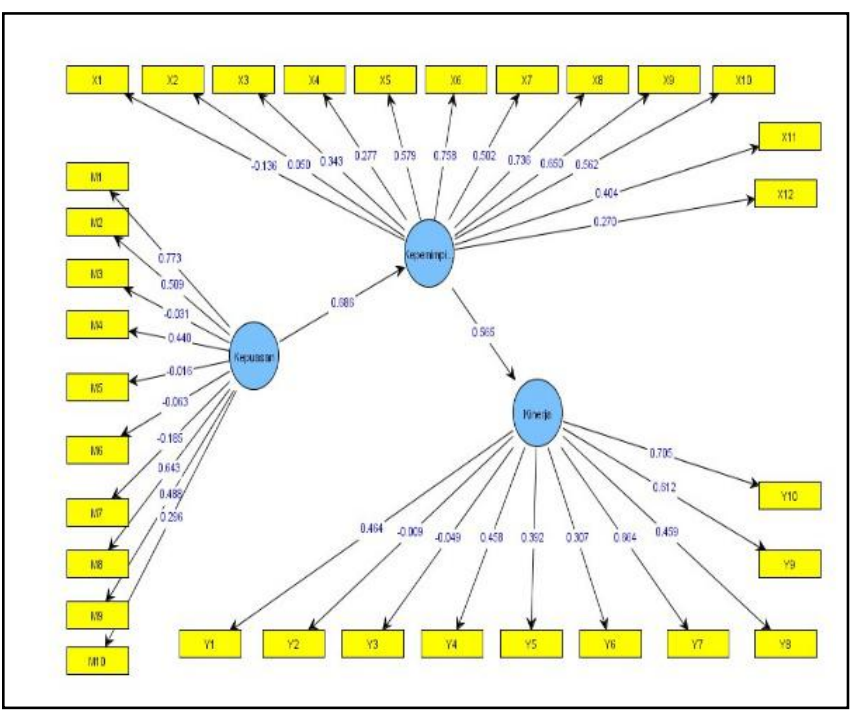

Gambar 3. Hasil analisis pengaruh kepuasan teradap kepemimpinan.

Kepemimpinan berpengaruh terhadap kinerja. Berdasarkan gambar di atas, maka dapat diketahui bahawa kepuasan karyawan berpengaruh positif dan signifikan terhadap kepemimpinan dengan koefisien regresi 0,686 dan nilai statistik $\mathrm{T}=3,018 \quad(>1,96)$. Sedang variabel kepemimpinan sebagai variabel intervening berpengaruh positif dan signifikan terhadap variabel kinerja dengan koefisien regresi sebasar 0,565 dan nilai statistik $\mathrm{T}=3,413(>1,96)$. Kedua nilai koefisien regresi (esimate paramater) tersebut signifikan seperti hasil uji signifikansi pada tabel di bawah ini:

Tabel 12. Hasil analisis pengaruh kepuasan terhadap kepemimpinan dan kepemimpinan terhadap kinerja

\begin{tabular}{|c|c|c|}
\hline Penoarul variabel & $\begin{array}{c}\text { original sample essimate } \\
\text { (keffisien regressis) }\end{array}$ & T.Statisic \\
\hline Kenuasan - Kepenimpinan & 0.680 & 3.018 \\
\hline Kepenimpinan $\rightarrow$ Kineria & 0.565 & 3.413 \\
\hline
\end{tabular}

Berdasarkan hasil analisis di atas maha dapat diketahui besarnya pengaruh langsung dari variabel kepuasan terhadap kepemimpinan sebesar 0,686, dan besarnya pengaruh langsung dari variabel kepemimpinan terhadap kinerja sebesar 0,565 . Sedang pengaruh tidak langs dari variabel kepuasan terhadap kinerja melalui variabel intervening kepemimpinan sebesar 0,388 seperti hasil perhitungan.

Pengaruh langsung kepemimpinan transaksional (X) terhadap kepuasan karyawan (M) dengan nilai koefisien regresi 0,586 dengan nilai statistik $T$ sebesar 6,080 (lebih besar dari 1,96). Hal tersebut menunjukkan bahwa variabel kepemimpinan transaksional memberikan pengaruh positif dan signifikan terhadap kepuasan karyawan. Hal ini berarti hasil dari pelaksanaan aktivitas manajerial kepemimpinan yang dijalankan mempunyai dampak yang positif atau baik bagi organisasi. Sesuai dengan teori : Robbins, Dimensi kepemimpinan berdasarkan perilaku ${ }^{12}$, Lima aspek yang terdapat dalam kepuasan kerja, yaitu: pekerjaan itu sendiri (work it self), penyelia (supervision), teman sekerja (workers), promosi (promotion), gaji/upah (pay). ${ }^{14}$ 
Hipotesa yang menyatakan gaya kepemimpian transaksional mempunyai pengaruh yang signifikan terhadap kepuasan kerja diterima.

Pengaruh langsung kepemimpinan transaksional (X) terhadap kinerja karyawan (Y) dengan nilai koefisien regresi 0,473 dengan nilai statistik $T$ sebesar 2,240 (lebih besar dari 1,96 ). Hal tersebut menunjukkan bahwa variabel kepemimpinan transaksional memberikan pengaruh positif dan signifikan terhadap kinerja karyawan. Hal ini berarti penerapan gaya kepemimpinan transaksional yang baik dapat meningkatkan kinerja karyawan, sesuai dengan teori: Cash, W.H. and F.E. Fischer. 1987. Human Resource Planning. ${ }^{15}$ Hipotesa yang menyatakan Gaya Kepemimpinan Transaksional mempunyai pengaruh yang signifikan terhadap Kinerja Karyawan diterima.

Pengaruh langsung kepuasan karyawan (M) terhadap kinerja karyawan (Y) dengan nilai koefisien regresi sebesar 0,160 dan nilai statistic $\mathrm{T}$ sebesar 0,776 ( lebih kecil dari 1,96) berati variabel kepuasan tidak berpengaruh terhadap kinerja karyawan. Secara umum kepuasan kerja karyawan masih rendah sehingga belum mampu meningkatkan kinerja karyawan, Hasil penelitian ini tidak sesuai dengan Koesmono, T. 2005, Pengaruh Budaya Organisasi Terhadap Motivasi dan Kepuasan Kerja Serta Kinerja Karyawan Pada Sub Sektor Industri Pengolahan Kayu Skala Menengah. ${ }^{13}$ Sehingga hipotesa yang menyatakan Kepuasan Kerja mempunyai pengaruh yang signifikan dengan Kinerja karyawan,hasil penelitian ini ditolak.

$\begin{array}{rcc}\text { Pengaruh } & \text { tidak } & \text { langsung } \\ \text { kepemimpinan } & \text { transaksional } & \text { terhadap }\end{array}$

kinerja melalui variabel intervening kepuasan diperoleh nilai koefisien regresi sebesar 0,094. Nilai ini sangat kecil sehingga dapat disimpulkan bahwa variabel intervening kepuasan justru melemahkan pengaruh kepemimpinan terhadap kinerja. Hal ini berarti variabel kepuasan pada penelitian ini dengan masa kerja karyawan kurang dari 2 tahun sebanyak 28,3 \% sehingga nilai kepuasannya rendah. Sehingga hipotesa yang menyatakan Gaya Kepemimpinan Transaksional berpengaruh terhadap Kinerja karyawan dengan Kepuasan Kerja sebagai variabel Intervening, hasil penelitian ini ditolak atau tidak sesuai hipotesa.

Setelah melihat hasil diatas apabila dilakukan regresi maka kerugian yang didapat cukuplah besar, beberapa sub variabel yang ada tidak digunakan lagi karena indikator-indikator yang tidak valid (nilai loading kurang dari 0,5), sehingga peneliti mengembangkan dengan modifikasi model untuk mempertahankan sub variabel - sub variabel yang direduksi, didapat hasil sebagai berikut : hasil analisis di atas maha dapat diketahui besarnya pengaruh langsung dari variabel kepuasan terhadap kepemimpinan sebesar 0,686, dan besarnya pengaruh langsung dari variabel kepemimpinan terhadap kinerja sebesar 0,565 . Sedang pengaruh tidak langsung dari variabel kepuasan terhadap kinerja melalui variabel intervening kepemimpinan sebesar 0,388. Hal ini tidak sesuai dengan model awal yang menggambarkan kepuasan sebagai intervening. Pengaruh kepuasan terhadap kinerja dalam modifikasi model mempunyai pengaruh tidak langsung melalui kepemimpinan sebagai intervening, sehingga tidak bisa digunakan oleh peneliti. 
Dalam penelitian ini tetap menggunakan model awal dengan kepusan sebagai intervening bahwa variabel intervening Kepuasan justru melemahkan pengaruh Kepemimpinana terhadap kinerja.

\section{KESIMPULAN}

Kesimpulan yang didapatkan dari hasil penelitian adalah gaya kepemimpinan transakaional berpengaruh positif dan signifikan terhadap kepuasan karyawan rawat inap Rumah Sakit Puri Asih Salatiga. Gaya kepemimpinan transaksional berpengaruh positif dan signifikan terhadap kinerja karyawan rawat inap Rumah Sakit Puri Asih Salatiga.

Kepuasan kerja tidak berpengaruh langsung terhadap kinerja perawat rawat inap Rumah Sakit Puri Asih Salatiga. Gaya kepemimpinan transaksional tidak berpengaruh secara tidak langsung melalui kepuasan sebagai intervening terhadap kinerja perawat rawat inap RS Puri Asih Salatiga.

\section{UCAPAN TERIMA KASIH}

Peneliti mengucapkan terima kasih kepada Rumah Sakit Umum Puri Asri Salatiga dan Magister Ilmu Kesehatan Masyarakat Universitas Diponegoro.

\section{DAFTAR PUSTAKA}

1. Sugianto, F. A. Pengaruh motivasi kerja dan kepemimpinan terhadap kinerja karyawan. Jakarta; Erlangga; 2011 .

2. Robbins, S.P. Perilaku Organisasi. Jakarta; Penerbit Erlangga; 2002.

3. Bass. Leadership in organization; 1990; 98.

4. As'ad, M. Perilaku Organisasi. Jakarta; Bumi Aksara; 2000; 133.
5. Baron, R. M, Kenny, D. A. The moderator-mediator variable distinction in social psychological research: Conceptual, strategic, and statistical considerations; 1986.

6. Dhimas, C. A. Hubungan Kepuasan Kerja Dan Intensi Turn over Pada Perawat Di Rumah Sakit Umum Puri Asih Salatiga; 2015.

7. Harnoto. Turnover Intentions: Definisi, Indikasi, Dampak Turnover bagi Perusahaan dan Perhitungan Turnover; Agustus; 2009

8. Irvan Hartanto. Pengaruh Gaya KepemimpinanTransaksional

Terhadap Kinerja Karyawan Dengan Kepuasan Kerja Sebagai Variabel Interving Pada Cv.Timur Jaya; 2014.

9. Dahniar. Pengaruh Gaya Kepemimpinan Transformasional Dan Gaya Transaksional Terhadap Kinerja Organisasi Studi Kantor Pengawasan Dan Pelayanan Bea Dan Cukai Tipe Madya Pabean Banjarmasin; 2014.

10. Ina Ratnaningsih. Pengaruh Gaya Kepemimpnan Transformasional Dan Gaya Kepemimpinan Transaksional Pada Kinerja Pegawai Bappeda Bandung; 2014.

11. Qurratul Aini. Pengaruh Gaya Kepemimpinan Dan Kepuasan Kerja Terhadap Kinerja Perawat Di Ruang Rawat Inap A RSUP. Dr. Soeradji Tirtonegoro Klaten; 2014.

12. Robbins. Dimensi kepemimpinan berdarkan perilaku; 1996; 41

13. Bass, Bernard M. The Transactional Transformational Leadership Pardigm Trascend Organizational and National Boundaries; 1997. 
14. Avolio, B. J, Bass, B. M. \& Jung, D. I. Re-Examining the Components of Transformational andTransactional Leadership Using the Multifactor Leadership; 1999.

15. Cash and Fischer, W. H. and F. E. Fischer. Human Resource Planning; 1987. 